\title{
Ubiquitin-Conjugating Enzyme E2 T
}

National Cancer Institute

\section{Source}

National Cancer Institute. Ubiquitin-Conjugating Enzyme E2 T. NCI Thesaurus. Code C131524.

Ubiquitin-conjugating enzyme E2 T (197 aa, $\sim 23 \mathrm{kDa}$ ) is encoded by the human UBE2T gene. This protein plays a role in the modulation of Fanconi anemia complex DNA repair activity. 